\section{Bevacizumab: a new way of doing business?}

\begin{abstract}
This review highlights the history of the development of treatments for choroidal neovascularization (wct AMD). It examines how drug therapies have evolved for the management of age-related macular degeneration (AMD) and the value of randomised clinical trials in determining efficacy. Finally it examines the emerging practice of utilising bevacizumab for the treatment of choroidal neovascularization despite the lack of any phase III clinical trial data.

Eye (2006) 20, 985-987. doi:10.1038/sj.eye.6702501; published online 21 July 2006
\end{abstract}

Keywords: bevacizumab; age-related macular degeneration; avastin

The treatment of submacular choroidal neovascularisation (CNV) in all its guises is undergoing a quiet revolution. Direct laser photocoagulation of the vessels was for years the mainstay of intervention. The role of laser was carefully evaluated over many years with many large clinical trials. ${ }^{1}$ The contraindications were established as a result of negative trial results - the wrong turns on the road and the cul de sacs became apparent through painstaking, methodical research.

Thus it was that the classic extrafoveal lesions were treated with thermal laser while the management of subfoveal lesions remained controversial. $^{2}$

Surgical approaches to CNV were also evaluated systematically. Surgical excision of submacular vessels in age-related macular degeneration (AMD) damaged the pigment epithelium such that the net visual outcome was poor. ${ }^{3}$ Similar surgery for inflammatory disciform lesions fared rather better. ${ }^{4}$

The efficacy of other surgical procedures has been evaluated, albeit with a lower standard of scientific proof. The risks and benefits of limited and $360^{\circ}$ macular translocation and pigment epithelial transplantation are now quite well understood. $^{5-7}$

The introduction of photodynamic therapy with verteporfin (PDT) marked a change in AMD management. Now a drug was involved, not just a device (laser) or a surgical technique, and the standards applying to drug licensing had to be met. Large-scale and expensive clinical trials demonstrated those subgroups that could benefit. 8,9

At the same time, the marketing expertise and business disciplines of commercial pharmaceutical companies were introduced. Advertising and publicity was intense and was aimed at clinicians, regulators and the general public. The result was a rapid uptake of PDT in many parts of the world including the UK.

The discovery that vascular endothelial growth factor (VEGF) was important in modulating the behaviour of CNV marked a further turning point in treatment. ${ }^{10,11}$ Much of the research on VEGF had been carried out in the retinal vasculature and its role in the choroidal circulation was thought to be less important.

Once a target had been identified, strategies were soon devised to block VEGF with high specificity. Pegaptanib (Macugen) has been the subject of extensive phase III trials and is set for early licensing and rapid clinical uptake. ${ }^{12}$ Hard on its heels comes ranibizumab (Lucentis) that promises even better clinical results. ${ }^{13}$ It too is the subject of large phase III trials and is looking likely to follow the same commercial trajectory.

All the treatments mentioned above orbit like planets around scientific orthodoxy. Bevacizumab (Avastin, Genentech Inc., South San Francisco, CA, USA) has appeared like a comet, a bright and strange phenomenon in the night sky. The parent compound to ranibizumab, it is already licensed for the management of colorectal cancer. ${ }^{14}$ It was thought to be pharmacodynamically unsuited for the journey from the vitreous cavity to the subretinal space. ${ }^{15}$
'Southampton Eye Unit, Southampton General Hospital, Southampton, UK

${ }^{2}$ Human Genetics Divison, Southampton General Hospital, University of Southampton, Southampton, UK

Correspondence: A Lotery, Human Genetics Divison, Southampton General Hospital, University of Southampton, Tremona Road, Southampton S016 6YD, UK Tel: +440238079 4590; Fax: +440238079 4120 . E-mail: a.j.lotery@soton.ac.uk

Received: 21 May 2006 Accepted in revised form: 21 May 2006 Published online: 21 July 2006 
Systemic administration of bevacizumab in the management of $\mathrm{CNV}$ produced a significant reduction in retinal thickening and improvement in visual acuity in a small series. ${ }^{16}$ However, the small number of reports of bevacizumab injections into the vitreous cavity ${ }^{17-21}$ have in less than a year turned into massive widespread clinical use. In effect, a product not licensed for use in the eye has gone from the earliest phase I pilot study into a common treatment without going through any phase II or III trials.

What has driven this uptake is not so much that bevacizumab works (which does seem to be true) but that it is available and cheap. ${ }^{22}$ The twin facts that it is licensed for cancer treatment (and therefore can be acquired through normal channels) and that it comes in the large doses necessary for its cancer role have meant that the aliquot cost per eye injection may be tens of pounds rather than hundreds or thousands of pounds.

This would seem to be excellent news for desperate patients and an overburdened health service - if it is safe. There is a reason why drugs are forced to slog down the long hard road of phased clinical trials - the process can trap serious side effects before the drug goes on general release. Even late in phase III, a drug like natalizumab can show a nasty side and be withdrawn. ${ }^{23}$ If bevacizumab is safe, we have just witnessed a quantum leap in the management of CNV. If it is not, we might be witnessing the early stages of the largest legal case in the history of ophthalmology .... and this time the pharmaceutical industry will not be picking up the tab. Therefore, as a first step there is an urgent need for a randomised clinical trial to evaluate the role of bevacizumab in the management of AMD. The economic benefit to the NHS of using such a cheap drug to prevent blindness justifies government support for such a trial.

\section{References}

1 Macular Photocoagulation Study Group. Visual outcome after laser photocoagulation for subfoveal choroidal neovascularization secondary to age-related macular degeneration. The influence of initial lesion size and initial visual acuity. Arch Ophthalmol 1994; 112(4): 480-488.

2 Beatty S, Au Eong KG, McLeod D, Bishop PN. Photocoagulation of subfoveal choroidal neovascular membranes in age related macular degeneration: the impact of the macular photocoagulation study in the United Kingdom and Republic of Ireland. Br J Ophthalmol 1999; 83(10): 1103-1104.

3 Hawkins BS, Bressler NM, Miskala PH, Bressler SB, Holekamp NM, Marsh MJ et al. Surgery for subfoveal choroidal neovascularization in age-related macular degeneration: ophthalmic findings: SST Report No. 11. Ophthalmology 2004; 111(11): 1967-1980.

4 Atebara NH, Thomas MA, Holekamp NM, Mandell BA, Del Priore LV. Surgical removal of extensive peripapillary choroidal neovascularization associated with presumed ocular histoplasmosis syndrome. Ophthalmology 1998; 105(9): 1598-1605.

5 Machemer R. Macular translocation. Am J Ophthalmol 1998; 125(5): 698-700.

6 Toth CA, Freedman SF. Macular translocation with 360-degree peripheral retinectomy impact of technique and surgical experience on visual outcomes. Retina 2001; 21(4): 293-303.

7 Toth CA, Lapolice DJ, Banks AD, Stinnett SS. Improvement in near visual function after macular translocation surgery with 360-degree peripheral retinectomy. Graefes Arch Clin Exp Ophthalmol 2004; 242(7): 541-548.

8 Bressler NM, Bressler SB, Haynes LA, Hao Y, Kaiser PK, Miller JW et al. Verteporfin therapy for subfoveal choroidal neovascularization in age-related macular degeneration: four-year results of an open-label extension of 2 randomized clinical trials: TAP Report No. 7. Arch Ophthalmol 2005; 123(9): 1283-1285.

9 Barnes RM, Gee L, Taylor S, Briggs MC, Harding SP. Outcomes in verteporfin photodynamic therapy for choroidal neovascularisation-'beyond the TAP study'. Eye 2004; 18(8): 809-813.

10 Adamis AP, Shima DT. The role of vascular endothelial growth factor in ocular health and disease. Retina 2005; 25(2): 111-118.

11 Ferrara N. Vascular endothelial growth factor: basic science and clinical progress. Endocr Rev 2004; 25(4): 581-611.

12 Gragoudas ES, Adamis AP, Cunningham Jr ET, Feinsod M, Guyer DR, the VEGF Inhibition Study in Ocular Neovascularization Clinical Trial Group. Pegaptanib for neovascular age-related macular degeneration. $N$ Engl J Med 2004; 351(27): 2805-2816.

13 Heier JS, Antoszyk AN, Pavan PR, Leff SR, Rosenfeld PJ, Ciulla TA et al. Ranibizumab for treatment of neovascular age-related macular degeneration a phase I/II multicenter, controlled, multidose study. Ophthalmology 2006; 113(4): 642. e1-4.

14 Hurwitz H, Fehrenbacher L, Novotny W, Cartwright T, Hainsworth J, Heim W et al. Bevacizumab plus irinotecan, fluorouracil, and leucovorin for metastatic colorectal cancer. N Engl J Med 2004; 350(23): 2335-2342.

15 Mordenti J, Cuthbertson RA, Ferrara N, Thomsen K, Berleau L, Licko $\mathrm{V}$ et al. Comparisons of the intraocular tissue distribution, pharmacokinetics, and safety of ${ }^{125}$ I-labeled full-length and Fab antibodies in rhesus monkeys following intravitreal administration. Toxicol Pathol 1999; 27(5): 536-544.

16 Michels S, Rosenfeld PJ, Puliafito CA, Marcus EN, Venkatraman AS. Systemic bevacizumab (avastin) therapy for neovascular age-related macular degeneration: twelve-week results of an uncontrolled open-label clinical study. Ophthalmology 2005; 112(6): 1035-1047.

17 Avery RL, Pieramici DJ, Rabena MD, Castellarin AA, Nasir MA, Giust MJ. Intravitreal bevacizumab (avastin) for neovascular age-related macular degeneration. Ophthalmology 2006; 113(3): 363-372.

18 Iturralde D, Spaide RF, Meyerle CB, Klancnik JM, Yannuzzi LA, Fisher YL et al. Intravitreal bevacizumab (avastin) treatment of macular edema in central retinal vein occlusion: a short-term study. Retina 2006; 26(3): 279-284. 
19 Manzano RP, Peyman GA, Khan P, Kivilcim M. Testing intravitreal toxicity of bevacizumab (avastin). Retina 2006; 26(3): 257-261.

20 Rosenfeld PJ, Fung AE, Puliafito CA. Optical coherence tomography findings after an intravitreal injection of bevacizumab (avastin) for macular edema from central retinal vein occlusion. Ophthalmic Surg Lasers Imag 2005; 36(4): 336-339.

21 Shahar J, Avery RL, Heilweil G, Barak A, Zemel E, Lewis GP et al. Electrophysiologic and retinal penetration studies following intravitreal injection of bevacizumab (avastin). Retina 2006; 26(3): 262-269.

22 Reichel E. Intravitreal bevacizumab for choroidal neovascularization and cystoid macular edema: a cost-effective treatment? Ophthalmic Surg Lasers Imag 2005; 36(4): 270-271.

23 Chaudhuri A. Lessons for clinical trials from natalizumab in multiple sclerosis. BMJ 2006; 332(7538): 416-419. 